Doi: $10.15863 / \mathrm{TAS}$

\section{International Scientific Journal Theoretical \& Applied Science}

p-ISSN: 2308-4944 (print) e-ISSN: 2409-0085 (online)

Year: $2015 \quad$ Issue: $01 \quad$ Volume: 21

Published: $30.01 .2015 \quad$ http://www.T-Science.org

SECTION 21. Pedagogy. Psychology. Innovations in the field of education.
Ekaterina Alexeevna Bogunec

Account Manager of externs and personal affairs graduates externs

Moscow State University of economics, statistics and informatics, Russia katerina392781@,rambler.ru

Natalia Igorevna Reshetko associate of professor Moscow State University of economics, statistics and informatics, Russia

Natalia.Reshetko@,rambler.ru

\title{
INFLUENCE OF EDUCATIONAL INSTITUTE ON LABOR MARKET FORMATION IN RUSSIA
}

Abstract: This article describes the indicators of youth unemployment and identified major shortcomings of current educational system in Russia. As to the author's arguments were given official data from Rosstat, conducted a survey of graduates of the Russian Federation,analyzed the spectrum of offers of fellowships and provide recommendations to reduce youth unemployment. The article also revealed the reasons for lack of competitiveness of young professionals in the labor market of Russia, as well as substantiated cause-and-effect relationships.

Key words: educational institute, labor market, Russia.

Language: English

Citation: Bogunec EA, Reshetko NI (2015) INFLUENCE OF EDUCATIONAL INSTITUTE ON LABOR MARKET FORMATION IN RUSSIA. ISJ Theoretical \& Applied Science 01 (21): 22-27. doi: http://dx.doi.org/10.15863/TAS.2015.01.21.4

Market structure in modern economy is dominating. And that's why we have significant growth of competitiveness. In this situation employers must be operative and flexible and in HR management politics. Nowadays key factor of effectiveness stays for competence which is based on knowledge. That's why we have a serious problem in lack of qualified HR. For a long time business faces this problem and education policy and interest in quality of professional education becomes more important as for government structures, so as commercial ones, which invests in it a lot.

System of education of each state is very individual (due to mentality, setup of values, historical factors) - all this we can see in compare of USA and Japan. Individual approach and collective. That's why idea of creation of universal education system is unreal. We have specific situation in Russian education system but it has great influence on labor market situation.

If we conduct statistical analysis of youth unemployment in Russia we can highlight some points about reliability and up-to-date state policy in this question, but we also must put into consideration a little time of usage of this new system of higher education.

Education system with good structure is a first step to supplement of necessary qualification basis of specialists.. But many countries hurry up to take foreign successful experience. They try to reach unification in education and forget about individual features and characteristics signing up different pacts about cooperation in educational sphere. Russia stood on a way of foreign experience adaptation in educational sphere and that is the main reason why a lot of aspects stay unsolved or not developed. These factors slow down moment of full scale result. In our country educational system is not so oriented on practice like in Germany, which can be described as leader in educational standards. We face such problem as combining practice and education on fulltime form and problem in equality of theoretic knowledge and practical experience.

Let's analyze official statistics of youth unemployment which was published on Rosstat. Author sees the main problem in unstable policy in education sphere (report period - august 2014). In general number of registered unemployment at the end of 2014 relative segment of youth occupies in general $28,2 \%$, in this number

- Teenagers - $4,6 \%$

- 20-24 years old - $23,7 \%$

High rate of youth unemployment is noticed by state HR departments for a long time. In general number of unemployed same categories stands for $23,4 \%$ and $13,3 \%$. In comparison with previous reporting period youth unemployment rise on 0,4 and 0,1 percent points. And ratio of unemployed among teenagers (15-24 y.o.) higher than same ratio among older people (30-49 y.o.) on 3,7 percent. 
Before we continue to results of social queue about job application among alumni of Russian higher education facilities and statistics of employment on specialty, we need to have a look on international ratings of higher education facilities and take into consideration government policy that has influence on pupil's choice of their future profession and place of studying.

Due to information of British company QS (Quacquarelli Symonds) and "Social navigator" of MIA "Russia Today" only MGU participate in international ratio of 200 best universities. MGU strengthen its position this year (moved from №120 up to №114). This rating contained 800 positions for the first time, when information were gathering and there were 21 russian universities, which included 4 from St. Petersburg. We also must have into consideration, that this universities is situated everywhere in Russia, not only in capital, as we can think.

Let us see on top 15 universities of the world and find out which criteria from experts' point of view are the key ones during definition of education quality.

Table 1

International rating of top 15 higher education facilities due to British company QS (Quacquarelli Symonds) and "Social navigator" of MIA "Russia Today".

\begin{tabular}{|l|l|l|l|}
\hline \multicolumn{2}{|c|}{ Rating } & \multicolumn{1}{c|}{ Name of the university } & \multirow{2}{*}{ Country } \\
\cline { 1 - 2 } $\mathbf{2 0 1 3}$ & 1 & Massachusetts Institute of Technology & USA \\
\hline 3 & 2 & Cambridge University & UK \\
\hline 5 & 2 & Imperial College London & UK \\
\hline 2 & 4 & Harvard University & USA \\
\hline 6 & 5 & Oxford University & UK \\
\hline 4 & 5 & University College London & UK \\
\hline 7 & 7 & Stanford University & USA \\
\hline 8 & 8 & University of California & USA \\
\hline 10 & 9 & Princeton University & USA \\
\hline 8 & 10 & Yale University & USA \\
\hline 9 & 11 & University of Chicago & Switzerland \\
\hline 12 & 12 & $\begin{array}{l}\text { Swiss Federal Institute of Technology } \\
\text { in Zurich }\end{array}$ & USA \\
\hline 13 & 13 & University of Pennsylvania & USA \\
\hline 14 & 14 & Columbian University & USA \\
\hline 16 & 15 & John Hopkins University & \\
\hline
\end{tabular}

It is necessary to note that $67 \%$ of higher educational facilities from this list located in USA. This country become a leader in providing higher education services. Second place stands for UK - it has $26 \%$ in this market. And it is interesting that $40 \%$ of higher educational facilities can strengthen their position in this rating by improving main criteria of effectiveness for example that ones which was rated scientific reputation, reputation among employers, ratio of professors and students, share of foreign professors and students and scientific quotation of professors.

From author's point of view these criteria is the key ones in definition of education effectiveness because:

- home and foreign professors help us in comparison of studying one definite professional discipline;

- ratio of professors and students is necessary for process control and not only in quantity indicator, but also in quality - in Russia most professors have only theoretic basis, falling deep into terminological education (of course it is necessary), but students like practicing professors more because they can share their experience in interesting way and show the most interesting moments for their professional start. Another necessary moment is in work load of professors - the more groups they have and they get tired more quickly from job and give less attention to involvement of students into education process.

- Scientific quotation - in Russia most scientific articles that publishes in outsider scientific periodicals in author's opinion aimed to theoretical description of research objects and we have a full loss of innovational mean of science. The idea is in shortage of practice of students' projects - in the era of informational society, it is quite easier to use such methods of 
research as interview, research statistics of economical indicators, etc. In other words, definitions of analysis and synthesis nowadays applies only to information processing, but not to independent research process aimed to innovation.

- Reputation among employers - very necessary criteria, but for Russia is vice versa, because university reputation is not equal to qualification and professional level of its alumni, in other words - reputation of university and quality of education cannot be equal.

Let's have a look at indicators of top universities in this rating and compare them with one Russian university, which includes in top 200 rating MGU.

Table 2

Criteria of index of best worldwide universities according to to British company QS (Quacquarelli Symonds) and "Social navigator" of MIA "Russia Today".

\begin{tabular}{|c|c|c|c|c|c|}
\hline & criteria: & 1st place & 2nd place & 3rd place & $\begin{array}{c}\text { MGU (114th place } \\
\text { instead of 120) }\end{array}$ \\
\hline 1 & Scientific reputation & 100 & 100 & 99,9 & 86,1 \\
\hline 2 & Reputation among employers & 100 & 100 & 100 & 76,2 \\
\hline 3 & Ratio of professors and students & 100 & 99,9 & 99,8 & 99,2 \\
\hline 4 & Share of foreign professors & 99,8 & 95,6 & 100 & 10,9 \\
\hline 5 & Share of foreign students & 95,6 & 96,5 & 99,7 & 52,1 \\
\hline 6 & $\begin{array}{c}\text { Scientific quotation of } \\
\text { professors }\end{array}$ & 100 & 97,9 & 96,2 & 7,8 \\
\hline
\end{tabular}

We should pay attention to rating of MIT and its indexes aren't absolute, but it is a leader for 2 years and the most weak spot of MIT is in "share of foreign students" - 95,6 out of 100. It is necessary to note that the other two universities indexes in this sphere are higher, especially in Imperial College in
London, but the average score are lower. Politic of universities can't take into consideration all aspects in this sphere, but can offer only competitive advantage - that's why MGU is the only Russian university in top 200 of best world universities and the best university in Russia.

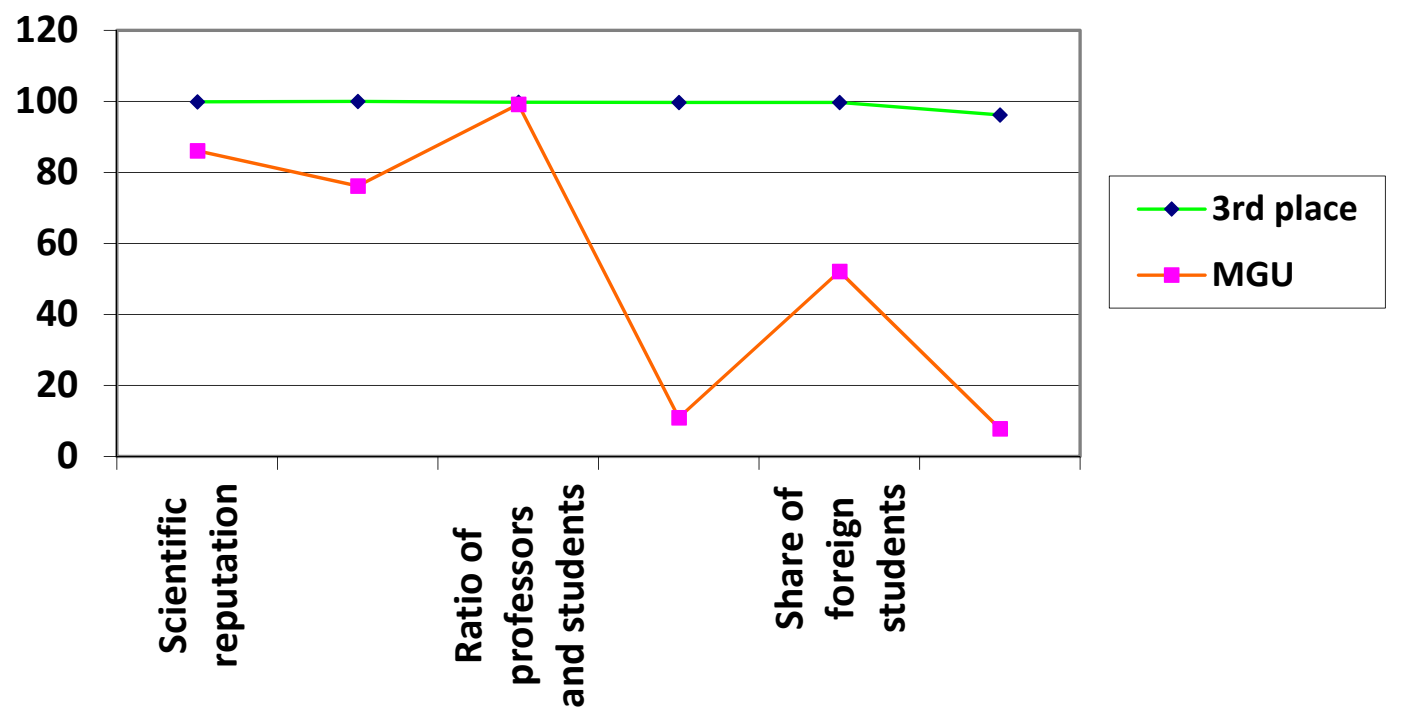

Figure 1 - Comparison of MGU (Russia) and Imperial College of London (UK) indexes.

On the picture above, we can see the difference in effectiveness between Imperial college of London and MGU. It is necessary to notice that the most important criteria for Russian labor market in MGU is near ideal state: scientific reputation, reputation among employers and ratio of professors and students. However, MGU is the only Russian university in this rating according to QS British 
Company (Quacquarelli Symonds) and "Social Navigator" MIA "Russia Today" and it shows us that Russia cannot be a competitor on a worldwide arena of education, though lead experts say that each year Russia is strengthening its position.
We must pay attention to Russia labor market, highlight employment statistics which was summed up from interview of alumni of Russian universities in September 2014. All respondents were graduated less than 2 years ago.

Table 3.

Comparison of professional spheres and level of young specialists' fees polarity after graduating.

\begin{tabular}{|c|c|c|}
\hline & popularity & Average fee \\
\hline Banking & $9,09 \%$ & 25800 \\
\hline IT-sphere & $12,12 \%$ & 50000 \\
\hline Sales & $15,15 \%$ & 26250 \\
\hline Marketing, advertising & $6,06 \%$ & 33000 \\
\hline Loader, courier & $12,12 \%$ & 18500 \\
\hline Guard & $6,06 \%$ & 30000 \\
\hline Interpreter, tutor & $6,06 \%$ & 23500 \\
\hline
\end{tabular}

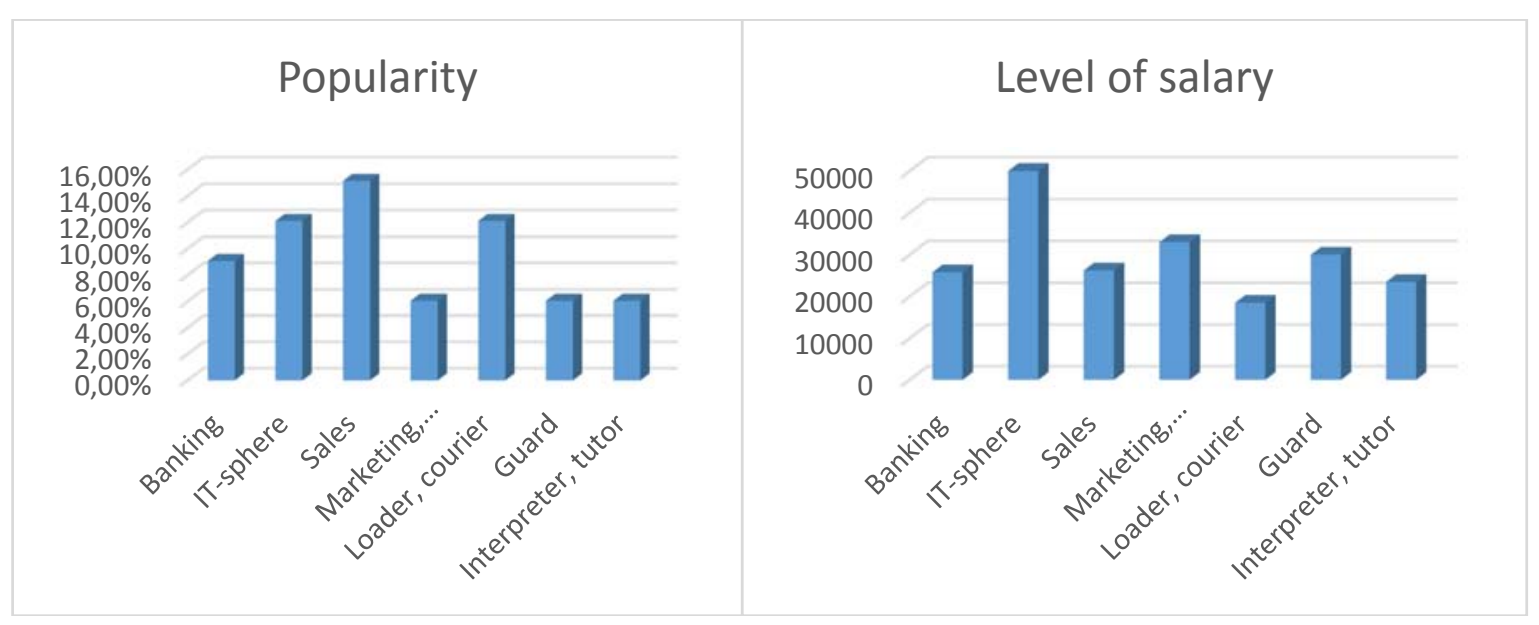

Figure 2 - Comparison of professional spheres and level of young specialists' fees polarity after graduating.

Comparing this two diagrams above we can notice that popularity of profession doesn't depend on level of salary so strong (from economical point of view excess in demand allows employers shorten salary level). Little demand or higher level of salaries are normal for professions which require not only qualification, but also knowledge (e.g. IT sphere, programming). It is necessary to highlight fact that alumni which cannot get a job by specialty occupies places for studying students, so we have a great percent of unemployed at the age of 15-19 years old and this don't allow to accumulate necessary competence basis.

If we analyze this data, we can say that professional education cannot give you the guarantee alumni $100 \%$ employment in their professional sphere, so we face another problem - re-qualification of employee with the help of commerce structures. From general number of respondents share of employed by profession, which they gained in university is $15,15 \%$ and this number can be cut, especially if we take into consideration that possibility of employment after medical university for example is near $85-90 \%$.

From economics in knowledge point of view, where competence is the key factor, highlighted professions plays a big role in formation of basic competence - that's why in case of avoid the politics of re-qualification and additional training with the help of commercial structures we need to support young workers employment not only on government level.

It is necessary to highlight main courses of youth employment policy in Russia:

- There are many educational programs by change, grants, but they are financing by interested organizations, especially by big companies. Government financing only budget places in universities, but they are still 
shortening - so this kind of stimulation become a course of government policy.

- Professional exhibitions, forums and conferences as a way to search talents commercial structures become a sponsor for many of them, where in discussion process and co-work experts choose candidates among students for further partnership. Another side of such conferences is that students can take experience from successful specialists, which show them main mistakes in their professional course.

- One course, which is the most perspective and can be used as a start for young people in business - is start-ups. They oriented on innovative development of business. In Russia only big companies, international commerce organizations, support start-ups in general. Their aim is to find some talents. In this case, young people cannot realize their human potential in general and can rise the economics of country to a new level. However, such practice gain its popularity

- Practice in commercial companies
Now we need to take a more detailed look on the last course in order to identify possibilities of young people in their professional development:

- In general, all probations are planning for 3month period or more in $2 / 2$ or $5 / 2$ mode full time.

- Probations can be seasonable, all year round, with or without payment (taking into consideration that students have free time in summer and ready to make some money).

- Depending on professional sphere workday can be variable from eight to twelve hours a day, so that is very tiring and exclude the opportunity to combine work and full-time studying, but many companies give flexible schedule and payment for result, not time payment.

- Salary is based on KPI in general - so flexible part of the salary depends only on employee, motivating.

As example we can look at the table of vacancies below

Table 4

Overview of youth probations in Russia for August-September 2014.

\begin{tabular}{|c|c|c|c|}
\hline Professional sphere & Schedule & Salary & Employer \\
\hline insurance & $2 / 2$ for 12 hours & Summary $80 \mathrm{~K}$, salary $20 \mathrm{~K}$ & Tinkoff \\
\hline Verification department & $2 / 2$ for 12 hours & Summary $90 \mathrm{~K}$, salary $22 \mathrm{~K}$ & Tinkoff \\
\hline Debt collection & $2 / 2$ for 12 hours & Summary $75 \mathrm{~K}$, salary $22 \mathrm{~K}$ & Tinkoff \\
\hline Telemarketing & $2 / 2$ or $5 / 2$ & Summary $80 \kappa$, salary $22 \kappa$ & Tinkoff \\
\hline Distant service operator & $2 / 2$ or $5 / 2$ & Summary $82 \kappa$, salary $25 \kappa$ & Tinkoff \\
\hline Sales & $5 / 2$ & discussing & Bosch \\
\hline Sales & Flexible schedule & $18-27 \kappa$ & MTS \\
\hline Manager on probation & $5 / 2$ & $63 \kappa$ plus year bonus & $\begin{array}{l}\text { British American } \\
\text { Tobacco Russia }\end{array}$ \\
\hline $\begin{array}{c}\text { Marketing/Advertaising/PR, } \\
\text { Sales }\end{array}$ & Flexible schedule & $10 \kappa-20 \kappa$ & FutureToday \\
\hline IT, Consulting & $5 / 2$ & Discussed & $\begin{array}{c}\text { Consulting } \\
\text { Graduate Analyst } \\
\text { (FMCG and Retail } \\
\text { Industry) }\end{array}$ \\
\hline $\begin{array}{c}\text { Probation in audit } \\
\text { department }\end{array}$ & $5 / 2$ & Discussed & PWC \\
\hline
\end{tabular}


Therefore, if we take into consideration a data above we can say that many employers nowadays are eager to spend finance for training and development of young specialists and with the help of probations have some qualification reserve that informed about specifics of actions in company. Variety of probations not limited by publishing vacancies of FutureToday Company. Many private persons are interested in this direction. Government has less interest in this, because in case of market economy development employers direct the course of labor market development by showing requirements to the candidate.

By highlighting main weaknesses of state policy in educational sphere and youth unemployment we can recommend:
- Strengthen universities and employers partnership that defines definite level of professionalism and professional competence of specialists. In other words - support practice part of students' education.

- Develop informational and law systems

- Develop educational system, offered base of knowledge, create possibilities for combining theory and practice during education.

- Help young people in business government and private financing in human resources through startup system.

\section{References:}

1. Ivanova-Shvec LN (2009) Management of work resourses. Moscow, EAOI.

2. Ivanova-Shvec LN, Korsakova AA, Tarasova SL (2008) Personnel management. Moscow, EAOI.

3. Sayt poiska raboty. Available: http://www.hh.ru (Accessed: 06.01.2015).

4. HR-Community and publications. Available: http://www.hr-portal.ru

(Accessed: 06.01.2015).

5. Association of Managers in Russia. Available: http://www.amr.ru (Accessed: 06.01.2015).
6. Journal recruitment business. Available: http://www.kdelo.ru/ (Accessed: 06.01.2015).

7. Lenta.ru. Available: http://lenta.ru (Accessed: 06.01.2015).

8. Training School Natalia Samoukina. Available: http://www.samoukina.ru (Accessed: 06.01.2015).

9. Rosstat official site. Available: http://www.gks.com (Accessed: 06.01.2015).

10. FutureToday official site. Available: http://fut.ru (Accessed: 06.01.2015). 